LA W RENCE LIVERMORE NATIONAL LABORATORY

Neutron source capability assessment for cumulative fission yields measurements

M. A. Descalle, W. Dekin, J. Kenneally

April 12, 2011 
This document was prepared as an account of work sponsored by an agency of the United States government. Neither the United States government nor Lawrence Livermore National Security, LLC, nor any of their employees makes any warranty, expressed or implied, or assumes any legal liability or responsibility for the accuracy, completeness, or usefulness of any information, apparatus, product, or process disclosed, or represents that its use would not infringe privately owned rights. Reference herein to any specific commercial product, process, or service by trade name, trademark, manufacturer, or otherwise does not necessarily constitute or imply its endorsement, recommendation, or favoring by the United States government or Lawrence Livermore National Security, LLC. The views and opinions of authors expressed herein do not necessarily state or reflect those of the United States government or Lawrence Livermore National Security, LLC, and shall not be used for advertising or product endorsement purposes.

This work performed under the auspices of the U.S. Department of Energy by Lawrence Livermore National Laboratory under Contract DE-AC52-07NA27344. 


\section{Neutron source capability assessment for cumulative fission yields measurements}

Marie-Anne Descalle, Walter Dekin, Jacqueline Kenneally

Lawrence Livermore National Laboratory, Livermore CA

\section{Motivation}

A recent analysis of high-quality cumulative fission yields data for $\mathrm{Pu}-239$ published in the peer-reviewed literature showed that the quoted experimental uncertainties do not allow a clear statement on how the fission yields vary as a function of energy.

[Prussin2009] To make such a statement requires a set of experiments with well "controlled" and understood sources of experimental errors to reduce uncertainties as low as possible, ideally in the 1 to $2 \%$ range.

The Inter Laboratory Working Group (ILWOG) determined that Directed Stockpile Work (DSW) would benefit from an experimental program with the stated goal to reduce the measurement uncertainties significantly in order to make a definitive statement of the relationship of energy dependence to the cumulative fission yields. Following recent discussions between Lawrence Livermore National Laboratory (LLNL) and Los Alamos National Laboratory (LANL), there is a renewed interest in developing a concerted experimental program to measure fission yields in a neutron energy range from thermal energy $(0.025 \mathrm{eV})$ to $14 \mathrm{MeV}$ with an emphasis on discrete energies from 0.5 to $4 \mathrm{MeV}$. Ideally, fission yields would be measured at single energies, however, in practice there are only "quasi-monoenergetic" neutrons sources of finite width. This report outlines a capability assessment as of June 2011 of available neutron sources that could be used as part of a concerted experimental program to measure cumulative fission yields. In a framework of international collaborations, capabilities available in the United States, at the Atomic Weapons Establishment (AWE) in the United Kingdom and at the Commissariat à l'Énergie Atomique (CEA) in France are listed.

\section{Methods}

The neutron sources described in this report were identified in two ways. Two internet databases, the Research Reactor database published by IAEA and the Research and Test Facility database published by NEA/OECD were mined. [IAEA2010][OECD2009] Search parameters ranged from country, operational status, beam types to possibility of experiments, applications and others. Simultaneously, experimentalists were asked for suggestions. Interestingly, there was a very good overlap between their recommendations and what was found in the databases.

Selection of the facilities to contact for further information and potential inclusion in this compilation was done based on the internet search and experimentalist's recommendations. Commercial reactors, reactor facilities without a webpage, or those facilities that could be identified as focused on teaching and training were not contacted. 
Points-of-contact were identified for each neutron source via the web or through experimentalists that had some knowledge of the facility. They were contacted by email and were asked to give information according to the set of criteria described in the first column of table 1 to 5 .

Several neutron source facilities were initially contacted but were not included in the analysis for the following reasons:

- No answer was received.

- The facilities are specialized fission or monoenergetic sources dedicated to specific research topics, such as material sciences research at the Oakridge Neutron Sciences Center, which operates the Spallation Neutron Source (SNS) and the High Flux Isotope Reactor (HFIR).

- The facilities indicated that they were dedicated to training and education.

While striving for completeness, it is entirely possible that some sources were not included which should have been. Please feel free to contact the authors with information on those facilities for inclusion.

\section{Capabilities}

The results are presented in table 1 to 5 . Table 1 and 2 show US monoenegetic and fission neutron sources. Some US white neutron sources are given in Table 3. They were included for the sake of completeness. Although the type of experiments currently envisioned will rely on well-characterized fission or monoenergetic sources, it is entirely possible that experiments using white sources will be planned later on.

Two potential neutron sources have been identified by our AWE point of contact. The Accelerator Steady Pulse (ASP) at AWE Aldermaston and the 3.5 megaelectron Volt $(\mathrm{MeV})$ Van den Graaff accelerator at the National Physical Laboratory. At this time, it is unclear if the necessary authorizations to conduct experiments with special nuclear material are in place. In case they are not, the time required to obtain such authorizations is not known.

Several CEA neutron sources have been identified. The High Flux Reactor at the Institut Laue-Langevin (HFR/ILL) in Grenoble delivers the highest thermal flux of all facilities. Orphee is a reactor with at least one user-based beam line. Two fast flux critical assemblies Caliban and Prospero may be available at Valduc/DAM. Finally, a 4.0 MeV Van den Graaff accelerator is available at Bruyère-le-Châtel, and can deliver neutron beams with energy from 0.5 to $4 \mathrm{MeV}$ as well as $14 \mathrm{MeV}$ depending on the ion beam/target configuration. All facilities appear to have the necessary authorizations to conduct experiments with special nuclear material.

AWE and CEA capabilities are described in Table 4.

During this assessment, it became clear that there is a fourth category of sources, those that are not currently operational but could be available. These include four "classic" fast critical assemblies (Godiva, Comet, Flat Top and Planet) which were recently moved to a 
dedicated facility at the Nevada Nuclear Security Site (NNSS). These assemblies, previously located at Los Alamos National Laboratory, were well characterized and used in criticality and reaction ratio benchmark experiments for decades.[NEA2005] The Dense Plasma Focus (DPF) fusion source at NNSS could be modified specifically for this experimental program and the $7 \mathrm{MeV}$ accelerator that was used for the cargo neutron interrogation project at LLNL could be restarted. The $2 \mathrm{MV}$ tandem accelerator at the TAMU Nuclear Science Center would need a license to produce neutrons. These capabilities are summarized in Table 5.

\section{Conclusion}

There is a need to develop an experimental program that will reduce the measurement uncertainties significantly in order to make a definitive statement of the relationship of energy dependence to the cumulative fission yields.

Fission and monoenergetic neutron sources are available that could support these fission yield experiments in the US, as well as at AWE and CEA.

Considerations that will impact the final choice of experimental venues are:

- Availability during the timeframe of interest

- Ability to accommodate special nuclear materials

- Cost

- Availability of counting facilities

- Expected experimental uncertainties

\section{References}

[Prussin2009] Prussin S. et al. Review of the Status of Cumulative Fission Yields from 239Pu(n,f) of Interest to Nuclear Forensics ( LLNL-TR-458777) 2009.

[IAEA2010] http://www-naweb.iaea.org/napc/physics/research reactors/database/RR Data Base/datasets/foreword_home.html accessed July 2010 http://www.iaea.org/worldatom/rrdb/

[OECD2009] Research and test facilities required in nuclear sciences and technology OECD/NEA 2009 ISBN 978-92-64-99070-8 / NEA No. 6293.

www.new. fr/rtfdb accessed July 2010.

[NEA2005] NEA Nuclear Science Committee 2005, "International Handbook of Evaluated Criticality Safety Benchmark Experiments" OECD NEA/NSC/DOC(95)03 September 2005 Edition.

This work performed under the auspices of the U.S. Department of Energy by Lawrence Livermore National Laboratory under Contract DE-AC52-07NA27344. 
Table 1. Fission sources

\begin{tabular}{|c|c|c|c|c|c|c|c|}
\hline $\begin{array}{l}\text { website } \\
\text { Facility name } \\
\text { Facility location } \\
\text { Facility status }\end{array}$ & $\begin{array}{l}\text { http://mnrc.ucdavis.ed } \\
\text { u/about.html } \\
\text { McClellan Nuclear } \\
\text { Research Center } \\
\text { Sacramento, CA } \\
\text { operational }\end{array}$ & $\begin{array}{l}\text { http://web.mit.edu/nrl/ } \\
\text { www/ } \\
\text { MIT Reactor Lab } \\
\text { MIT, Cambridge, MA } \\
\text { operational }\end{array}$ & & & & $\begin{array}{l}\text { http://www.murr.miss } \\
\text { ouri.edu/ } \\
\text { MUUR } \\
\text { Washington Univ, } \\
\text { Columbia, MI } \\
\text { operational }\end{array}$ & $\begin{array}{l}\text { http://neutrons.ornl.go } \\
\text { v/facilities/HFIR/ } \\
\text { High Flux isotope } \\
\text { reactor (HFIR) } \\
\text { Neutron Sciences } \\
\text { Oakridge National Lab. } \\
\text { operational }\end{array}$ \\
\hline $\begin{array}{l}\text { Facility contact } \\
\text { information }\end{array}$ & $\begin{array}{l}\text { Moe Boussoufi } \\
\text { Experiment } \\
\text { Coordinator/Radioisoto } \\
\text { pe Manager } \\
\text { tel: (916) 614-6200 } \\
\text { toll free: (888) 377- } \\
7957 \\
\text { fax: (916) 614-6250 } \\
\text { mboussoufi@ucdavis.e } \\
\underline{\text { du }} \\
\text { general email: } \\
\text { mnrc@ucdavis.edu }\end{array}$ & $\begin{array}{l}\text { Tom Newton Associate } \\
\text { Director, Reactor } \\
\text { Engineering } \\
\text { tel: (617) 253-4211 } \\
\text { tnewton@mit.edu }\end{array}$ & & & & $\begin{array}{l}\text { MUUR Director } \\
\text { (thermal } \\
\text { beams)@missouri.edu } \\
\text { tel: (916) 614-6200 } \\
\text { customer servces: } 573 \\
882-4211 \\
\text { murrinquiries@missour } \\
\text { i.edu } \\
\text { Dr. J. David Robertson } \\
\text { Associate Director, } \\
\text { Research and } \\
\text { Education } \\
\text { tel: (573) 882-5346 } \\
\text { (MURR) } \\
\text { RobertsonJo@missouri. } \\
\text { edu } \\
\text { Dr. John Brockman } \\
\text { Assistant Res. Prof. } \\
\text { University of Missouri } \\
\text { Res. Reactor Center } \\
\text { Research Park Drive } \\
\text { Columbia, MO 65211 } \\
\text { tel: (573) 884-8095 } \\
\text { (MURR) } \\
\text { brockmanJD@missouri. } \\
\text { edu }\end{array}$ & $\begin{array}{l}\text { Chris Bryan } \\
\text { Experiments and } \\
\text { Isotope production } \\
\text { Neutron Sciences } \\
\text { Oak Ridge National } \\
\text { Laboratory } \\
\text { tel: (865) 241-4336 } \\
\text { bryancd@ornl.gov }\end{array}$ \\
\hline $\begin{array}{l}\text { Beam source } \\
\text { Beam line ID } \\
\text { description }\end{array}$ & $\begin{array}{l}\text { Nuclear reactor } \\
\text { Bay\#4 } \\
3 \mathrm{E}+05 \mathrm{n} / \mathrm{cm} 2 / \mathrm{s} @ 1 \\
\mathrm{MW} \\
\begin{array}{l}4.5 \mathrm{E}+05 \mathrm{n} / \mathrm{cm}^{2} / \mathrm{s} \\
\text { (thermal flux) }\end{array}\end{array}$ & $\begin{array}{l}\text { Nuclear reactor: } 4 \\
\text { beam lines } \\
\text { 4DH1 } \\
\text { Student chopper beam }\end{array}$ & $\begin{array}{l}\text { 4DH3 } \\
\text { Prompt gamma } \\
\text { diffracted beam } \\
\sim 1 \mathrm{E}+07 \mathrm{n} / \mathrm{cm}^{2} / \mathrm{s}\end{array}$ & $\begin{array}{l}\text { White beam of } 1 \text { inch } \\
\text { diameter: } 1 \mathrm{E}+07 \\
\text { neutrons } / \mathrm{cm}^{2} / \mathrm{s} \text { and } \\
\text { Monochromatic beam } \\
2 \times 3 \text { inch, } 14.7 \mathrm{MeV}: \\
3 \mathrm{E}+06 \text { neutrons } / \mathrm{cm}^{2} / \mathrm{s}\end{array}$ & $\sim 1 \mathrm{E}+10 \mathrm{n} / \mathrm{cm}^{2} / \mathrm{s}$ & $\begin{array}{l}\text { Nuclear reactor } \\
\text { Most thermal neutron } \\
\text { beam in new small } \\
\text { animal BNCT testing } \\
\text { facility }\end{array}$ & $\begin{array}{l}\text { High Flux Nuclear } \\
\text { Reactor } \\
\text { Multiple irradiation } \\
\text { locations and } 4 \text { beams } \\
\text { Neutron scattering } \\
\text { experiments, Neutron } \\
\text { Activation Analysis } \\
\text { (NAA), isotope } \\
\text { production } \\
3 \mathrm{E}+15 \mathrm{n} / \mathrm{cm} 2 / \mathrm{s} @ 85 \\
\mathrm{MW} \\
\\
\text { Thermal flux: } \\
4.3 \mathrm{E}+14-2.5 \mathrm{E}+15 \\
\mathrm{n} / \mathrm{cm}^{2} / \mathrm{s} \text { depending on } \\
\text { in-vessel location } \\
3 \text { thermal and } 1 \text { cold } \\
\text { beam tubes } \\
\text { (to } 10 \text { neutron } \\
\text { scattering instruments) }\end{array}$ \\
\hline
\end{tabular}




\begin{tabular}{|c|c|c|c|c|c|c|c|}
\hline $\begin{array}{l}\text { Beam energy } \\
\text { level(s) (?mev } \\
\text { neutrons) }\end{array}$ & $\begin{array}{l}\text { Thermal flux has } \\
\text { maxwellian spectrum } \\
(<1 \mathrm{eV}) \text { Fast flux }(>1 \\
\text { MeV) has half the value } \\
\text { of the thermal }\end{array}$ & $\begin{array}{l}\text { Thermal spectrum at } \\
\text { about } 50 \mathrm{C} \text {, with } \\
\text { epithermal component } \\
\text { at about } 1 \mathrm{eV}\end{array}$ & & $\begin{array}{l}\text { Thermal beam, } \\
\text { (calculated thermal } \\
\text { flux energy distribution } \\
\text { available). Fast } \\
\text { neutron flux unknown }\end{array}$ & Thermal beam & Cd ratio of 129 & $\begin{array}{l}\text { In-vessel thermal } \\
\text { beam, }>0.111 \mathrm{MeV} \\
,>0.821 \mathrm{MeV} \\
\text { Pneumatic tubes: } \\
\text { PT-1: Thermal Neutron } \\
\text { Flux: } 4 \mathrm{E}+14 \mathrm{n} \mathrm{cm}^{-2} \mathrm{~s}^{-1} \\
\text { Thermal/epithermal } \\
\text { ratio: } 40 \\
\text { PT- } 2 \text { : Thermal } \\
\text { Neutron Flux: } 4 \mathrm{E}+13 \mathrm{n} \\
\mathrm{cm}^{-2} \mathrm{~s}^{-1} \\
\text { Thermal/epithermal } \\
\text { ratio: } 200\end{array}$ \\
\hline $\begin{array}{l}\text { How does the facility } \\
\text { characterize the } \\
\text { beam intensity and } \\
\text { energy - detectors, } \\
\text { standards, } \\
\text { calibration }\end{array}$ & $\begin{array}{l}\text { Gold foils and } \mathrm{Cd}- \\
\text { covered gold foils }\end{array}$ & 要 & $\begin{array}{l}\text { Gold foils } \\
\end{array}$ & (1) & $\begin{array}{l}\text { Gold foils, graphite and } \\
\text { tissue equivalent } \\
\text { proportional counters }\end{array}$ & $\begin{array}{l}\text { Thermal, epithermal } \\
\text { and fast flux foils were } \\
\text { inradiated to check the } \\
\text { models. The a priori } \\
\text { neutron spectrum was } \\
\text { calculated using DORT. } \\
\text { Based on the measured } \\
\text { activities of the foils } \\
\text { and the corrected cross } \\
\text { sections of the flux } \\
\text { foils a least squares } \\
\text { algorithm was used to } \\
\text { calculate an adjusted } \\
\text { detailed spectrum. } \\
\text { Summary table } \\
\text { available. The thermal } \\
\text { beam was constructed } \\
\text { using silicon crystal } \\
\text { and bismuth crystal } \\
\text { filters and as a result } \\
\text { there is a significant } \\
\text { fraction of epithermal } \\
\text { neutrons in the range } \\
\text { of } 214 \text { eV o } 297,000 \\
\text { eV ( } 3.2 \% \text { of total flux). }\end{array}$ & \\
\hline $\begin{array}{l}\text { How well } \\
\text { characterized is the } \\
\text { beam }\end{array}$ & & $\begin{array}{l}\text { Energy is well } \\
\text { characterized, intensity } \\
\text { not well characterized }\end{array}$ & $\begin{array}{l}\text { Full spectrum not } \\
\text { available, but could be } \\
\text { done by using foils. } \\
\text { Gammas can be } \\
\text { filtered by Bi filter, but } \\
\text { gammas were not } \\
\text { measured. }\end{array}$ & $\begin{array}{l}\text { Well characterized for } \\
\text { BNCT irradiations }\end{array}$ & & & $\begin{array}{l}\text { Well characterized in } \\
\text { core flux }\end{array}$ \\
\hline $\begin{array}{l}\text { What is beam spot } \\
\text { size? }\end{array}$ & $\begin{array}{l}1.25 \text { in } \times 1.25 \text { in } \\
\text { aperture with an L/D } \\
\text { ratio of } 270\end{array}$ & $\begin{array}{l}\text { Approximately } 0.5 \times 10 \\
\text { mm, final collimation } \\
\text { could be changed to } \\
\text { increase spot size to } \\
\text { about } 2 \times 20 \mathrm{~mm}\end{array}$ & $\sim 2 \mathrm{~cm}$ diameter & $\begin{array}{l}\text { Variable, up to } 2 \times 3 \\
\text { inch. }\end{array}$ & $\begin{array}{l}\text { Variable, up to } 15 \mathrm{~cm} \\
\text { diameter }\end{array}$ & $\begin{array}{l}\text { Neutron flux is } \\
\text { homogenous ( }<10 \% \\
\text { variation) across the } \\
\text { beams } 6 \text {-in diameter } \\
\text { with the neutron flux } \\
\text { decreasing sharply } \\
\text { outside the } 6 \text {-in } \\
\text { diameter beam }\end{array}$ & $\begin{array}{l}\text { H1B- H3B: } 2.75 \text {-in } x \\
5.5 \text {-in. rectangular } \\
\text { aperture. } \\
\text { H2B: } 6 \text {-in tall } \times 10 \text {-in } \\
\text { wide }+ \text { additional } \\
\text { collimation } \\
\text { H4B: collimator } \\
\text { provides } 3 \text { rectangular } \\
\text { apertures with } \\
\text { outboard dim: } 1.61 \text { in } \times \\
4.33 \text { in; } 2.17 \text { in } \times 3.65\end{array}$ \\
\hline
\end{tabular}




\begin{tabular}{|c|c|c|c|c|c|c|c|}
\hline & & & & & & & in; 1.78 in $\times 4.33$ in. \\
\hline $\begin{array}{l}\text { Evaluation of beam } \\
\text { anisotropy - how } \\
\text { isotropic is the beam } \\
\text { that the target will } \\
\text { see? }\end{array}$ & $\begin{array}{l}\text { Quasi parallel beam, } \\
\text { with a L/D ratio of } 270\end{array}$ & & $\begin{array}{l}\text { FWHM from } \\
\text { monochrometer is } 2.4 \\
\text { degrees }\end{array}$ & $\begin{array}{l}\text { The beam is pretty } \\
\text { isotropic, maximum } \\
\text { beam divergence is } \\
\text { about } 1 \text { degree. The } \\
\text { divergence can be } \\
\text { reduced by collimators. }\end{array}$ & d & Very collimated & \\
\hline $\begin{array}{l}\text { Evaluation of room } \\
\text { return. }\end{array}$ & N/A & N/A & N/A & N/A & $\begin{array}{l}\text { Insignificant (floor is } \\
10 \text { feet from beam } \\
\text { entrance on ceiling) }\end{array}$ & $\begin{array}{l}\text { Did not observed a } \\
\text { significant } \\
\text { "bounceback" at the } \\
\text { irradiation position in } \\
\text { the thermal beam. The } \\
\text { entire irradiation } \\
\text { chamber is covered } \\
\text { with a boron containing } \\
\text { rubber or silicon to cut } \\
\text { down on room return. } \\
\text { The shielding was } \\
\text { purchased from } \\
\text { Shieldwerx (formally } \\
\text { thermal, formally } \\
\text { reactor experiments). } \\
\text { We use both the SWX- } \\
\text { 227A flexi panel ( } 9 \% \\
\text { boron) and the SWX- } \\
238 \text { Flexi boron ( } 25 \% \\
\text { boron) in different } \\
\text { areas of the chamber. }\end{array}$ & N/A \\
\hline $\begin{array}{l}\text { Is there a standard } \\
\text { simulation input for } \\
\text { the facility? (input } \\
\text { deck for MCNP) }\end{array}$ & Yes, MCNP run & 更 & & 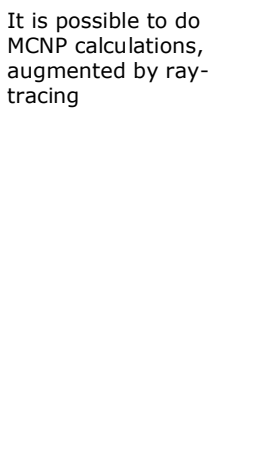 & MCNP & $\begin{array}{l}\text { Beam modeled using } \\
\text { the DORT code with a } \\
\text { modified } 59 \text { group } \\
\text { cross section table } \\
\text { (expanded from the } 47 \\
\text { energy group Bugle- } 80 \\
\text { library to add detail the } \\
\text { thermal section.) The } \\
\text { DORT code was used } \\
\text { to construct a source } \\
\text { plane for a detailed } \\
\text { MCNPS model located } \\
\text { just before the } \\
\text { irradiation position. } \\
\text { thermal, epithermal } \\
\text { and fast flux foils were } \\
\text { irradiated to check the } \\
\text { models }\end{array}$ & $\begin{array}{l}\text { MCNP } \\
\text { ORNL/TM-2004/251 }\end{array}$ \\
\hline $\begin{array}{l}\text { Facility sample } \\
\text { analysis/characteriz } \\
\text { ation capability - } \\
\text { what equipment/ } \\
\text { detectors, } \\
\text { standards, } \\
\text { calibration }\end{array}$ & $\begin{array}{l}\text { Four High purity } \\
\text { Germanium detectors }\end{array}$ & $\begin{array}{l}\text { High purity Germanium } \\
\text { detector }\end{array}$ & $\begin{array}{l}\text { High purity } \\
\text { Germanium detector }\end{array}$ & $\begin{array}{l}\text { Au foils, } \mathrm{He} 3 \text { and } \\
\text { scintillator detectors, } \\
\text { ASTM imaging } \\
\text { standards }\end{array}$ & In beam $\mathrm{BF} 3$ detectors & & $\begin{array}{l}\text { Neutron Activation } \\
\text { Analysis with two } \\
\text { pneumatic shuttle } \\
\text { system (Be reflector) } \\
\text { Hydraulic shuttle } \\
\text { irradiation facility (high } \\
\text { flux core) }\end{array}$ \\
\hline
\end{tabular}




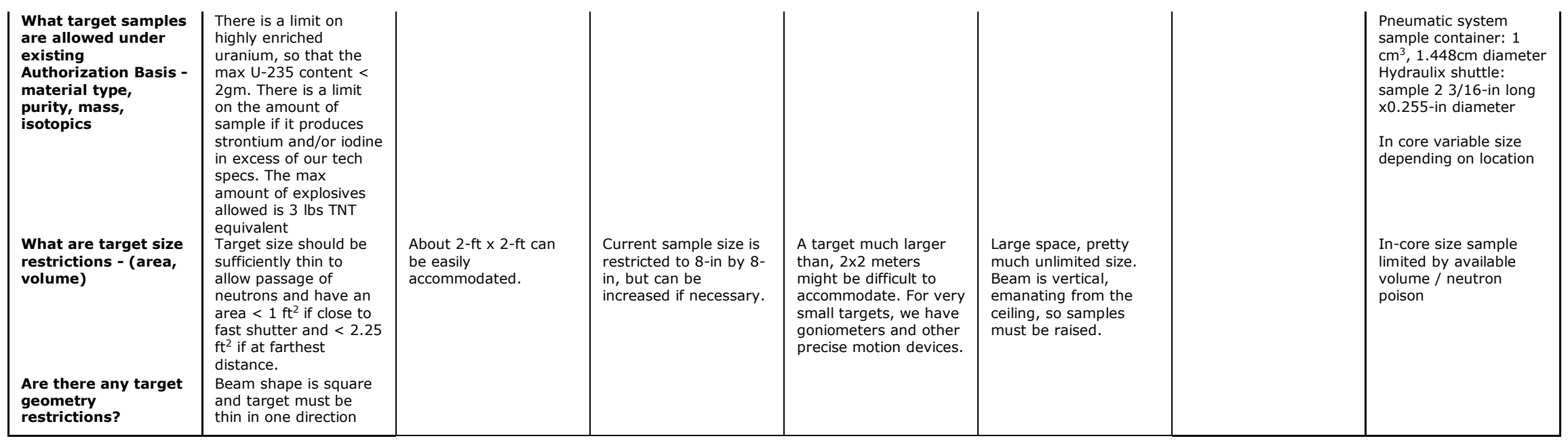


Table 2. Monoenergetic sources

\begin{tabular}{|c|c|c|}
\hline $\begin{array}{l}\text { website } \\
\text { Facility name } \\
\text { Facility location } \\
\text { Facility status }\end{array}$ & $\begin{array}{l}\text { http://edwards1.phy.ohiou.edu/ oual } \\
\text { Edwards Accelerator Laboratory } \\
\text { Ohio University, Athens, OH } \\
\text { Operational } \\
\text { Dr. David C. Ingram } \\
\text { Edwards Accelerator Laboratory, Rm106 } \\
\text { Department of Physics and Astronomy } \\
\text { University Terrace, Ohio University } \\
\text { Athens, Ohio } 45701-2979 \\
\text { tel: (740) } 593-1705 \text { (office) } \\
\text { tel: (740) } 593-986 \text { (laboratory) } \\
\text { fax: (740) 593-1436 } \\
\text { ingram@ohio.edu }\end{array}$ & $\begin{array}{l}\text { http://www.tunl.duke.edu/ } \\
\text { TUNL - Triangle Universities Nuclear Laboratory } \\
\text { Duke University, Durham, NC } \\
\text { Operational } \\
\text { Dr. Anton P. Tonchev } \\
\text { Department of Physics } 410 \text { TUNL } \\
\text { Duke University } \\
\text { Durham, NC } \\
\text { tel: (919) 660-2636 (office) } \\
\text { fax: (919) 660-2634 (fax) } \\
\text { tonchev@tunl.duke.edu } \\
\text { Dr. Henry R. Weller } \\
\text { tel: (919) 660-2633 (office) } \\
\text { fax: (919) 660-2634 (fax) } \\
\text { weller@tunl.duke.edu }\end{array}$ \\
\hline Beam source & $\begin{array}{l}\text { 4MeV tandem accelerator } \\
d, d \mathrm{~d}, \mathrm{t}, \mathrm{p}, \mathrm{t} \text {, are often used but many other reactions are possible } \\
\text { Target } \mathrm{T}(\mathrm{solid}, \mathrm{gas}) ; \mathrm{D}(\mathrm{solid}, \text { gas); } \\
3 \mathrm{He} \text { (gas); } 15 \mathrm{~N}(\mathrm{gas})- \\
\text { Solid target: } \mathrm{Li}, \mathrm{Be}, \mathrm{B}, \mathrm{C}, \mathrm{Al} \text { - some are single isotope. }\end{array}$ & Tandem accelerator, $2 \mathrm{H}(\mathrm{D}, \mathrm{n}) 3 \mathrm{He}$ and $3 \mathrm{H}(\mathrm{p}, \mathrm{n}) 3 \mathrm{He}$ reactions. \\
\hline $\begin{array}{l}\text { Available beam intensity } \\
(1 \times 10 ? \text { neutrons/cm sq/sec })\end{array}$ & $\begin{array}{l}\text { Depends on the reaction - } \\
\text { Up to } 10 \mathrm{E}+13 \text { neutrons; } 20 \mathrm{~cm} \text { from source } 10 \mathrm{E}+7 \text { neutrons } / \mathrm{cm}^{2} / \mathrm{s} \\
6 \text { beam lines (one is } 30 \mathrm{~m} \text { TOF tunnel, well shielded, with beam swinger) see } \\
\text { email below }\end{array}$ & $\begin{array}{l}\text { Neutron flux }=0.5 \mathrm{n} / \mathrm{cm} \odot / \mathrm{s} \text { from } 2 \text { microA beam current on } 7 \mathrm{~atm} \text { ( } 103 \text { PSI) } \\
\text { pressurized gas cell. } \\
\text { This neutron beam is not collimated, except for "Shielded source area" where } \\
\text { the beam is well collimated through a shielding wall. } \\
\text { Typically run with } 200 \mathrm{~ns} \text { between bursts, but this can be varied up to a } \\
\text { microsecond. } \\
\text { Sample distance to the end of the gas cell }=4.5 \mathrm{~cm} .\end{array}$ \\
\hline $\begin{array}{l}\text { Beam energy level(s) (?mev } \\
\text { neutrons) }\end{array}$ & Neutrons from $0.5-20 \mathrm{MeV}$ can be produced depending on the reaction used & $\begin{array}{l}\text { First reaction: monoenergetic } n \text {-beams from } 4 \text { to } 18 \mathrm{MeV} \text {. } \\
\text { Second reaction: neutrons from } 1.5 \text { to } 7 \mathrm{MeV} \text {. }\end{array}$ \\
\hline $\begin{array}{l}\text { How does the facility } \\
\text { characterize the beam intensity } \\
\text { and energy - detectors, } \\
\text { standards, calibration }\end{array}$ & $\begin{array}{l}\text { Charge on target known within } 10 \% \text {. Apertured system with an aperture that } \\
\text { can be varied from a few to } 20 \mathrm{~cm} \text { in diameter- Reference article on neutron } \\
\text { energy measurements available. The terminal voltage was calibrated using well } \\
\text { known nuclear reactions and the calibration transferred to an NMR system used } \\
\text { in combination with a mass analysis magnet. Beam currents are measured in } \\
\text { suppressed mode or in faraday cups depending on the design of the } \\
\text { experimental system. The current is integrated with a beam current integrator } \\
\text { that is occasionally checked with the Keithley constant current source. }\end{array}$ & $\begin{array}{l}\text { We rely on the activation monitors from } \mathrm{Au}, \mathrm{Al} \text {, and } \mathrm{Ni} \text { foils. You can use neutron } \\
\text { detector in the beam and simulate the detector efficiency with MCNP to get the } \\
\text { absolute neutron flux. }\end{array}$ \\
\hline $\begin{array}{l}\text { How well characterized is the } \\
\text { beam }\end{array}$ & $\begin{array}{l}\text { Very well, but it depends on what it means. Pulsing and bunching (timing } \\
\text { information, precise neutron energy characteristics) }\end{array}$ & Monitoring of the time fluctuation of the $n$-beam using neutron detectors. \\
\hline What is beam spot size? & $\begin{array}{l}\text { Usually less than } 3 \mathrm{~mm} \text { diameter, one beam line has as scanner for irradiation of } \\
1 \mathrm{~cm}^{2} \text { samples. }\end{array}$ & $\begin{array}{l}\text { Collimated neutron beam is used for in-beam measurements. However in this } \\
\text { case the neutron flux on target position }(2.5 \mathrm{~m} \text { from the gas cell }) \text { is } 2-\mathrm{E}+04 \\
\mathrm{n} / \mathrm{cm}^{2} / \mathrm{s} \text { with average beam current }(2 \mathrm{H} \text { beam) of } 1.5 \text { microA. The collimated } \\
\text { neutron beam has a diameter of } 4.5 \mathrm{~cm} \text {. }\end{array}$ \\
\hline
\end{tabular}




\begin{tabular}{|c|c|c|}
\hline $\begin{array}{l}\text { Evaluation of beam anisotropy } \\
\text { - how isotropic is the beam } \\
\text { that the target will see? }\end{array}$ & It is focused but is probably a gaussian & The beam is rather isotropic according to measurements with films. \\
\hline Evaluation of room return. & This can be done, but is not usually done. No known evaluation of room return & $\begin{array}{l}\text { Does not know if measurements were done. With neutron detectors like Li-glass, } \\
\text { can measure down to } 50 \mathrm{keV} \text {. } \\
\text { Maybe can use different monitor foils (In, } \mathrm{Cd}, \mathrm{V} \text {, ect.) to extract the very low } \\
\text { energy component of the thermal part of the } n \text {-spectrum. }\end{array}$ \\
\hline $\begin{array}{l}\text { Is there a standard simulation } \\
\text { input for the facility? (input } \\
\text { deck for MCNP) }\end{array}$ & James Hall @ LLNL developed a COG input deck & no standard input deck but do run MCNPX \\
\hline $\begin{array}{l}\text { Facility sample } \\
\text { analysis/characterization } \\
\text { capability - what equipment/ } \\
\text { detectors, standards, } \\
\text { calibration }\end{array}$ & RBS, ERS, XPS, SAM, NRA... Counting detectors: $\mathrm{HpGe}, \mathrm{BGO}, \mathrm{NaI}$ & $\begin{array}{l}\text { Do have all type of HPGe detectors, neutron detectors, NaI, plastic, charge } \\
\text { particle, He3- proportional chamber, etc. } \\
\text { Do have all common used gamma, neutron, and alpha callibrated sources. } \\
\text { Not equipped for radiochemical or mass separation analysis. } \\
\text { Neutron time of flight setup: an open geometry which uses "shadow "bars to } \\
\text { shield the neutron detectors from source neutrons }\end{array}$ \\
\hline $\begin{array}{l}\text { What target samples are } \\
\text { allowed under existing } \\
\text { Authorization Basis - material } \\
\text { type, purity, mass, isotopics }\end{array}$ & $\begin{array}{l}\text { Existing license for radioactive target } \mathrm{Pu}-239100 \text { microCi sealed source } \\
\text { (encapsulated } \mathrm{Pu}-\mathrm{Be} \text { ) }\end{array}$ & $\begin{array}{l}\text { All stable targets are allowed. If the target is an actinide target, then we need a } \\
\text { license permission to run. }\end{array}$ \\
\hline $\begin{array}{l}\text { What are target size } \\
\text { restrictions - (area, volume) } \\
\text { Are there any target geometry } \\
\text { restrictions? }\end{array}$ & $\begin{array}{l}\text { Depends on the beamline and on whether the target is in vacuum or not. } \\
\text { See previous question. }\end{array}$ & $\begin{array}{l}\text { For stable targets there are not size restriction. For actinides, the limit is the } \\
\text { University license regulation. } 4 \text { grams of } 239 \mathrm{Pu} \text { (maxed during Micah Jonhson's } \\
\text { experiment) } \\
\text { No }\end{array}$ \\
\hline
\end{tabular}


Table 3. White neutron sources

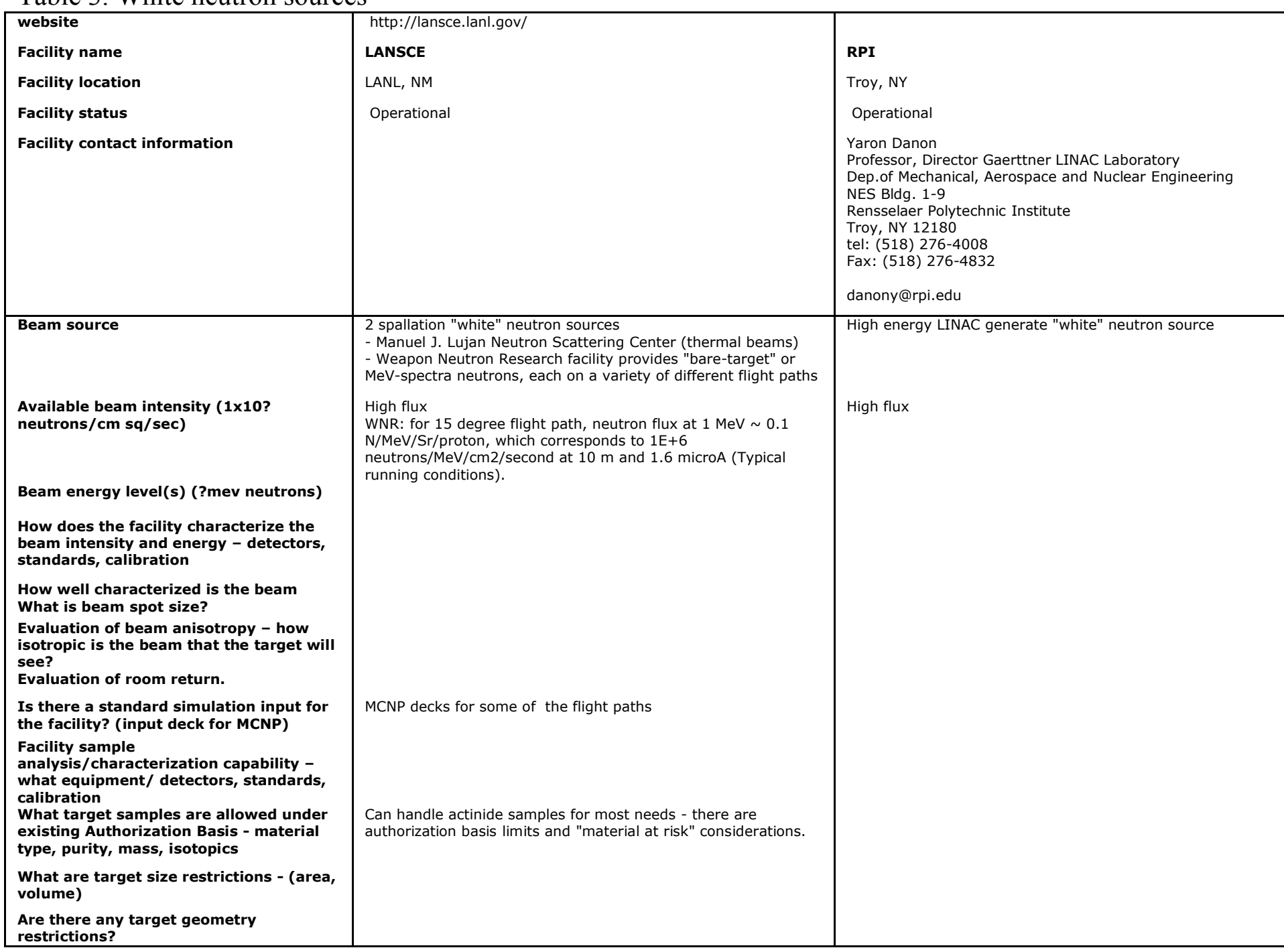


Table 4. AWE and CEA capabilities

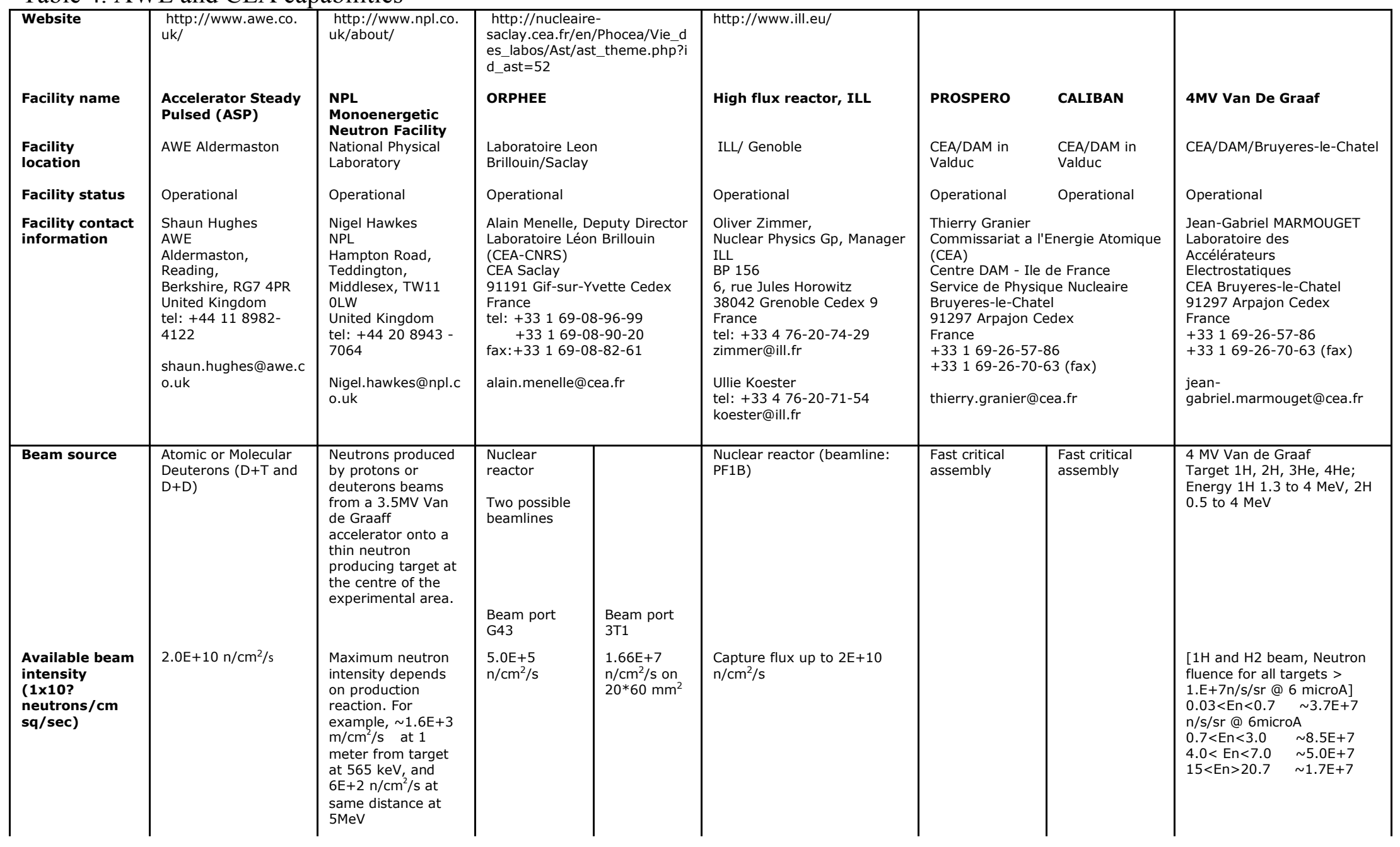




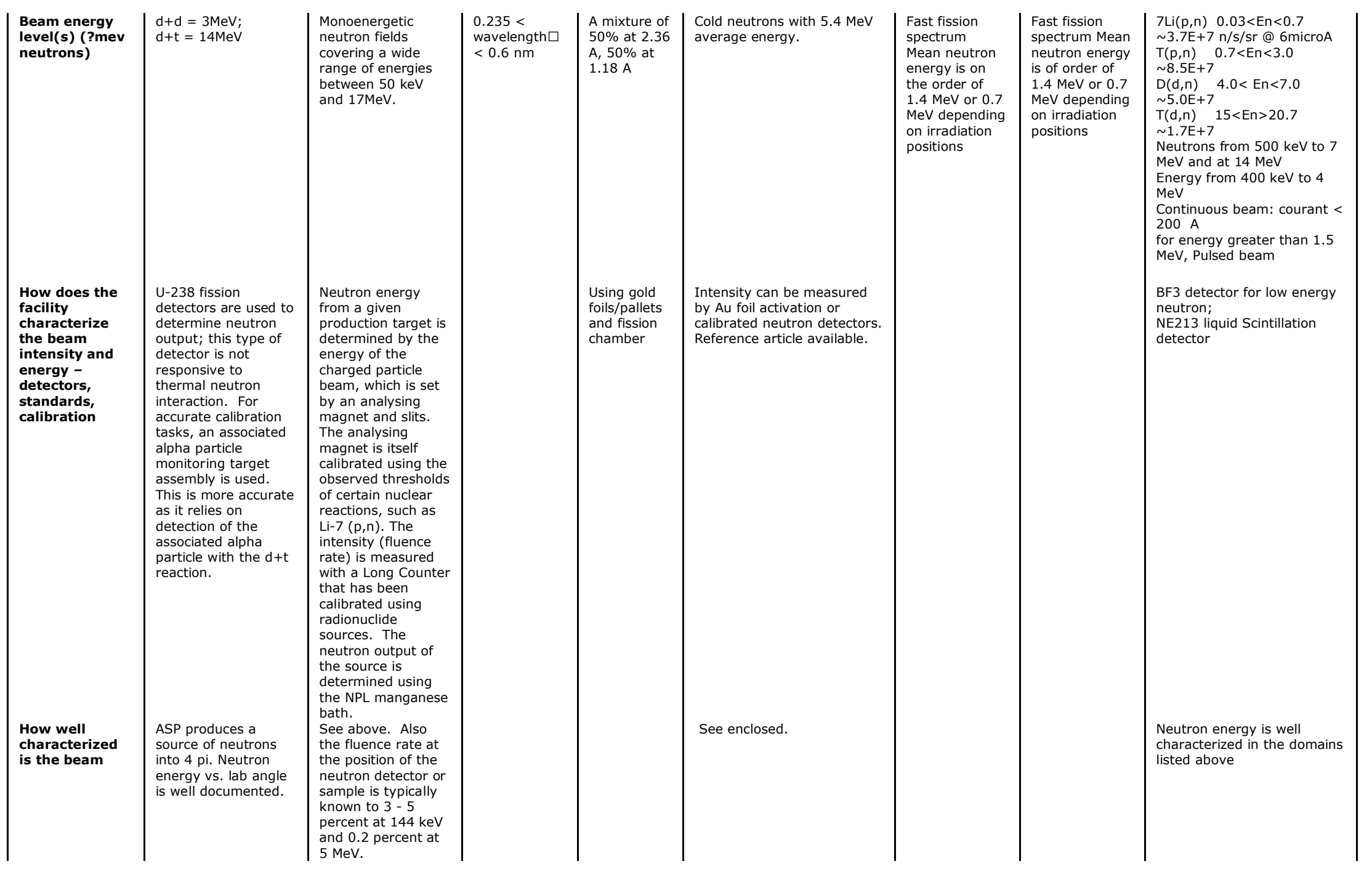




\begin{tabular}{|c|c|c|c|c|c|}
\hline $\begin{array}{l}\text { What is beam } \\
\text { spot size? }\end{array}$ & See above. & $\begin{array}{l}\text { Neutrons are } \\
\text { emitted in } 4 \mathrm{pi}, \\
\text { neutron fields } \\
\text { rather than beams. }\end{array}$ & $\begin{array}{l}\text { Width : } 25 \\
\mathrm{~mm} \text {; height } \\
50 \mathrm{~mm}\end{array}$ & & $\begin{array}{l}\text { The full beam covers } 20 \mathrm{~cm} \\
\text { (height) by } 6 \mathrm{~cm} \text { (width). It } \\
\text { can be collimated to any } \\
\text { smaller size. }\end{array}$ \\
\hline $\begin{array}{l}\text { Evaluation of } \\
\text { beam } \\
\text { anisotropy - } \\
\text { how isotropic } \\
\text { is the beam } \\
\text { that the target } \\
\text { will see? }\end{array}$ & $\begin{array}{l}\text { Neutron energy off } \\
\text { accelerator target } \\
\text { varies with angle. } \\
\text { Neutrons emitted at } \\
0 \text { deg, i.e. directly in } \\
\text { front of the target } \\
\text { will have a higher } \\
\text { energy than those } \\
\text { emitted at an angle } \\
\text { of say } 97 \text { deg. In } \\
\text { this case: } 0 \text { deg will } \\
\text { yield an energy of } \\
\text { approximately } 14.6 \\
\text { MeV, whilst at } 97 \text { deg } \\
\text { the energy will be } \\
14.0 \text { MeV. }\end{array}$ & $\begin{array}{l}\text { The neutron field } \\
\text { covers the face of } \\
\text { the detector or } \\
\text { sample. If this } \\
\text { represents a wide } \\
\text { range of emission } \\
\text { angles the variation } \\
\text { in energy and } \\
\text { intensity can be } \\
\text { calculated using } \\
\text { relativistic } \\
\text { kinematics. }\end{array}$ & & $\begin{array}{l}\text { quite large } \\
\sim 30 \%\end{array}$ & See enclosed. \\
\hline $\begin{array}{l}\text { Evaluation of } \\
\text { room return. }\end{array}$ & $\begin{array}{l}\text { No data is available } \\
\text { for this as primary } \\
\text { interest is fast } \\
\text { neutrons. However } \\
\text { the target cell has } \\
\text { been designed as a } \\
\text { low scatter } \\
\text { environment. }\end{array}$ & $\begin{array}{l}\text { The neutron } \\
\text { producing target is } \\
\text { at least } 6 \text { meters } \\
\text { away from the } \\
\text { floor, walls and } \\
\text { ceiling of the } \\
\text { experimental area; } \\
\text { meaning that the } \\
\text { room return is } \\
\text { small. } \\
\text { Nevertheless, it is } \\
\text { routinely measured } \\
\text { by placing a } \\
\text { shadow cone } \\
\text { between the } \\
\text { production target } \\
\text { and the detector to } \\
\text { block all the } \\
\text { neutrons coming } \\
\text { directly from the } \\
\text { target. }\end{array}$ & & & $\begin{array}{l}\text { Depends on setup. Correct } \\
\text { shielding by } 6 \mathrm{Li}, 10 \mathrm{~B} \text {, etc. } \\
\text { containing materials } \\
\text { minimizes room return } \\
\text { usually to acceptable level } \\
(<<1 \mathrm{E}-4) \text {. }\end{array}$ \\
\hline $\begin{array}{l}\text { Is there a } \\
\text { standard } \\
\text { simulation } \\
\text { input for the } \\
\text { facility? (input } \\
\text { deck for MCMP) }\end{array}$ & No & $\begin{array}{l}\text { MCNP model of the } \\
\text { main features of } \\
\text { experimental area }\end{array}$ & & & $\begin{array}{l}\text { The reactor spectra are } \\
\text { simulated e.g. by MCNP and } \\
\text { can serve as input for } \\
\text { beamline simulations. }\end{array}$ \\
\hline
\end{tabular}

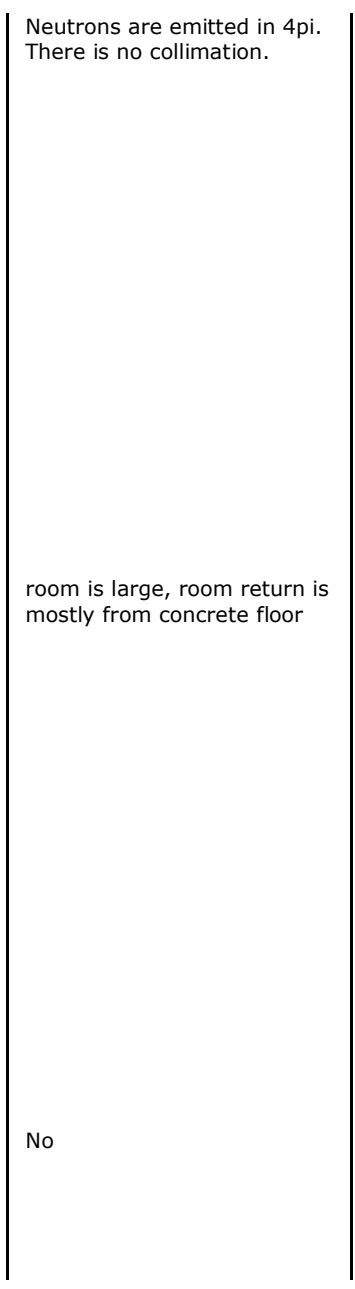




\begin{tabular}{|c|c|c|c|c|c|c|c|}
\hline $\begin{array}{l}\text { Facility sample } \\
\text { analysis/chara } \\
\text { cterization } \\
\text { capability - } \\
\text { what } \\
\text { equipment/ } \\
\text { detectors, } \\
\text { standards, } \\
\text { calibration }\end{array}$ & $\begin{array}{l}\text { ASP does not provide } \\
\text { any sample analysis } \\
\text { capability at present; } \\
\text { users would be } \\
\text { expected to provide } \\
\text { any sample } \\
\text { interrogation } \\
\text { equipment as part of } \\
\text { their trials plan. } \\
\text { There will in the near } \\
\text { future though be the } \\
\text { capability to perform } \\
\text { gamma spectroscopy } \\
\text { measurements. }\end{array}$ & $\begin{array}{l}\text { It would appear } \\
\text { not. But the facility } \\
\text { is only a short } \\
\text { distance from the } \\
\text { NPL Radioactivity } \\
\text { Group who have a } \\
\text { range of } \\
\text { instruments that } \\
\text { could potentially be } \\
\text { utilised for such } \\
\text { purposes. }\end{array}$ & $\begin{array}{l}\text { 3He/Ancillary } \\
\text { equipment } \\
\text { Be filter ( } 77 \\
\text { K) } \\
\text { Furnace (20 - } \\
\left.1200^{\circ} \mathrm{C}\right) \\
\text { Multidetector: } \\
\text { only in } \\
\text { diffraction } \\
\text { mode } \\
\text { (without } \\
\text { analyzer) } \\
\text { Triple Axis } \\
\text { Equipment } \\
\text { Pool }\end{array}$ & & $\begin{array}{l}\text { Sample should be } \\
\text { characterized before sending } \\
\text { to ILL. Usual gamma } \\
\text { calibration sources are } \\
\text { available. }\end{array}$ & & 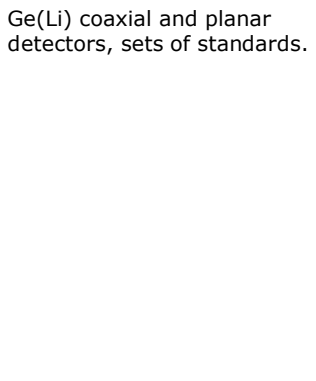 \\
\hline $\begin{array}{l}\text { What target } \\
\text { samples are } \\
\text { allowed under } \\
\text { existing } \\
\text { Authorization } \\
\text { Basis - material } \\
\text { type, purity, } \\
\text { mass, isotopics }\end{array}$ & $\begin{array}{l}\text { Currently ASP is not } \\
\text { permitted to hold or } \\
\text { irradiate any } \\
\text { explosive or fissile } \\
\text { material. Samples } \\
\text { required to be } \\
\text { irradiated must be } \\
\text { submitted with full } \\
\text { details of expected } \\
\text { isotopes produced } \\
\text { and any additional } \\
\text { radiological } \\
\text { precautions which } \\
\text { may be required. }\end{array}$ & $\begin{array}{l}\text { Most of the } \\
\text { detectors that they } \\
\text { calibrate are } \\
\text { inactive. However } \\
\text { they do have } \\
\text { authorisation for } \\
\text { samples containing } \\
\text { small quantities of } \\
\text { fissile material; } \\
\text { though it is unlikely } \\
\text { they would be able } \\
\text { to handle highly } \\
\text { active unsealed } \\
\text { samples. }\end{array}$ & & & $\begin{array}{l}\text { All elements and isotopes } \\
\text { are possible. General limit: } \\
8 \text { mg } 239 \text { Pu (as unspecified } \\
\text { compound with } 1 \text { um } \\
\text { granularity), other isotopes } \\
\text { and compounds scale with } \\
\text { radiotoxicity according to } \\
\text { French radioprotection rules. } \\
\text { Higher amounts are possible } \\
\text { at beamlines in the reactor } \\
\text { hall. They may also be } \\
\text { possible at PF1B on request } \\
\text { with special precautions } \\
\text { (enclosure...) }\end{array}$ & & $\begin{array}{l}\text { Actinides are ok up to } \\
\text { several grams. }\end{array}$ \\
\hline $\begin{array}{l}\text { What are } \\
\text { target size } \\
\text { restrictions - } \\
\text { (area, volume) }\end{array}$ & $\begin{array}{l}\text { No restrictions on } \\
\text { sample size. } \\
\text { However it is worth } \\
\text { bearing in mind when } \\
\text { producing trials plans } \\
\text { that the uniformity of } \\
\text { dose and irradiation } \\
\text { time will be affected } \\
\text { by the geometry of } \\
\text { the sample / } \\
\text { equipment under } \\
\text { testing in relation to } \\
\text { its position from the } \\
\text { neutron producing } \\
\text { target. }\end{array}$ & $\begin{array}{l}\text { The open geometry } \\
\text { of the experimental } \\
\text { area means that a } \\
\text { wide range of } \\
\text { sample sizes and } \\
\text { shapes cans be } \\
\text { accommodated. }\end{array}$ & $\begin{array}{l}\text { Space around } \\
\text { target } 2 * 2 \mathrm{~m}^{2}\end{array}$ & $\begin{array}{l}\text { Space } \\
\text { around } \\
\text { target } \\
1 * 1 \mathrm{~m}^{2}\end{array}$ & $\begin{array}{l}\text { Only restricted by user- } \\
\text { supplied experimental } \\
\text { chamber. }\end{array}$ & & No restriction \\
\hline $\begin{array}{l}\text { Are there any } \\
\text { target } \\
\text { geometry } \\
\text { restrictions? }\end{array}$ & As above. & As above. & $\begin{array}{l}\text { This type of } \\
\text { irradiation is } \\
\text { not done on } \\
\text { this beam } \\
\text { line, and will } \\
\text { require a } \\
\text { special safety } \\
\text { analysis to } \\
\text { define safety } \\
\text { procedures. it } \\
\text { could be quite } \\
\text { difficult for Pu }\end{array}$ & & $\begin{array}{l}\text { Only restricted by user- } \\
\text { supplied experimental } \\
\text { chamber. }\end{array}$ & No restriction & \\
\hline
\end{tabular}


Table 5. Future sources

\begin{tabular}{|c|c|c|c|c|c|}
\hline Website & & & & & http://nsc.tamu.edu/ \\
\hline Facility name & $\begin{array}{l}\text { Critical Experiment } \\
\text { Facility in the Device } \\
\text { Assembly Facility }\end{array}$ & $\begin{array}{l}\text { Dense Plasma Focus (DPF) } \\
\text { fusion neutron source }\end{array}$ & ALEXIS & 7 MEV accelerator & $\begin{array}{l}\text { TAMU Nuclear Science } \\
\text { Center }\end{array}$ \\
\hline Facility location & $\begin{array}{l}\text { Nevada Nuclear Security } \\
\text { Site, NV }\end{array}$ & NSTEC facility, NV & $L L N L, C A$ & $L L N L, C A$ & Texas A\&M, TX \\
\hline Facility status & $\begin{array}{l}\text { Not operational, limited } \\
\text { operation for testing (start } \\
\text { expected end FY2011) }\end{array}$ & Operational (need modification) & Not operational & $\begin{array}{l}\text { Not operational (in storage) } \\
\text { Information from cargo project }\end{array}$ & $\begin{array}{l}\text { Operational (need } \\
\text { modifications, and currently no } \\
\text { license to produce neutrons) }\end{array}$ \\
\hline Facility contact information & no point of contact & $\begin{array}{l}\text { Chris Hagen, NSTEC } \\
\text { hagenec@nv.doe.gov }\end{array}$ & $\begin{array}{l}\text { Larry Ahle, Jason Burke } \\
\text { tel: (925)422-4683 } \\
\text { burke26@llnl.gov }\end{array}$ & $\begin{array}{l}\text { Brian Rusnack } \\
\text { rusnak1@IInl.gov } \\
\text { brusnak@nps.edu }\end{array}$ & $\begin{array}{l}\text { Dr. Dan Reece, Director } \\
\text { Nuclear Science Center } \\
129 \text { Zachry Engin. Bldg } \\
3133 \text { TAMU } \\
\text { College Station, TX } 77843 \\
\text { tel: (979) 847-8946 } \\
\text { fax: (979) 845-8946 } \\
\text { w-reece@tamu.edu } \\
\\
\text { Prof. Leslie Braby } \\
\text { (2 MeV tandem accelerator) } \\
\text { tel: (979) 862-1798 } \\
\text { labraby@ne.tamu.edu }\end{array}$ \\
\hline Beam source & $\begin{array}{l}\text { 4 well characterized } \\
\text { benchmark critical } \\
\text { assemblies } \\
\text { (Godiva, Comet, FlatTop, } \\
\text { Planet) }\end{array}$ & $\begin{array}{l}\text { Yields } \sim 5 \times 1 \text { E12 neutrons per } \\
\text { pulse } \\
\text { Pulse widths between } 50 \text { and } 150 \\
\text { ns } \\
\text { Neutron production rates of up to } \\
1020 \text { neutrons per second, } \\
\text { Cycle time = } 5 \text { minutes. }\end{array}$ & $\begin{array}{l}3 \text { MeV Pelletron } \\
\text { Gas target \& solid target }\end{array}$ & $\begin{array}{l}4 \mathrm{MeV}, 425 \mathrm{MHz} \mathrm{D}^{=} \mathrm{RFQ} \\
\text { current } \mathrm{I}_{D}^{+} \sim 100 \mathrm{microA} \text { average } \\
D_{2} \text { target Gas cell } \\
10 \mu \mathrm{MO} \text { Moil }(\triangle E \approx 730 \mathrm{keV}) \\
P_{D 2} \approx 1 \text { atma (100 CFM flow rate) } \\
L=60 \mathrm{~cm} \text { (stopping target)s }\end{array}$ & $\begin{array}{l}2 \mathrm{MV} \text { tandem that has been } \\
\text { used in the past to make } \\
\text { neutrons using } \mathrm{DT}, \mathrm{DD} \text {, and } \mathrm{D}- \\
\text { carbon reactions. Two ion } \\
\text { sources - Duoplasmatron and } \\
\mathrm{RF} \text { source with rubidium charge } \\
\text { exchange }\end{array}$ \\
\hline $\begin{array}{l}\text { Anticipated beam intensity } \\
\text { (1x10? neutrons/cm sq/sec) }\end{array}$ & & $\begin{array}{l}\text { The new DPF will yield } 1 E+14 \\
\text { neutrons per shot, at ten shots per } \\
\text { day, } 1 E+15 \text { neutrons per } 6 \text { hour } \\
\text { day. }\end{array}$ & $\begin{array}{lc}20-40 \mathrm{keV} & 10^{7} \mathrm{n} / \mathrm{cm}^{2} / \mathrm{s} \\
1.3-1.7 \mathrm{MeV} & >10^{7} \mathrm{n} / \mathrm{cm}^{2} / \mathrm{s}^{*} \\
6.0-6.5 \mathrm{MeV} & >10^{8} \mathrm{n} / \mathrm{cm}^{2} / \mathrm{s} \\
14.4-14.6 \mathrm{MeV}>10^{7} \mathrm{n} / \mathrm{cm}^{2} / \mathrm{s}^{*}\end{array}$ & $\begin{array}{l}\Phi_{n} \approx 7.43 E+03 \mathrm{n} / \mathrm{cm}^{2} / \mu C(2.5 \\
m) \\
D_{n} \approx 0.25 \mathrm{mrem} / \mu \mathrm{C}(2.5 \mathrm{~m})\end{array}$ & $\begin{array}{l}\text { Small fluence production. } \\
\text { Dependent on target and } \\
\text { shielding }\end{array}$ \\
\hline $\begin{array}{l}\text { Beam energy level(s) (?mev } \\
\text { neutrons) }\end{array}$ & Fission spectrum & 2.45 MeV and $14 \mathrm{MeV}$ & & $E_{n}(\max ) \approx 6.54 \mathrm{MeV} @ 0^{\circ}$ & $\begin{array}{l}\text { Dependent on target, } \\
\text { potentially } 0 \text { to } 15 \mathrm{MeV} \\
\text { (hydrogen ion beams to } 4 \mathrm{MeV} \text { ) }\end{array}$ \\
\hline $\begin{array}{l}\text { How does the facility } \\
\text { characterize the beam } \\
\text { intensity and energy - } \\
\text { detectors, standards, } \\
\text { calibration }\end{array}$ & & & $\begin{array}{l}\text { * } 5 \text { Curie Tritium Target required } \\
\text { for this flux }\end{array}$ & & $\begin{array}{l}\text { Precision long counter for } \\
\text { intensity, neutron energy is } \\
\text { obtained from ion energy and } \\
\text { kinematics of the neutron } \\
\text { production reaction. Ion energy } \\
\text { is calibrated using the threshold } \\
\text { energy of the Li }(p, n) \text { reaction }\end{array}$ \\
\hline
\end{tabular}

